\title{
Thermal Performance of Apartment (High-Rise) in Surabaya with Precast Concrete for the Building Envelope
}

\author{
Romanria Violina Mahardhika1, Ima Defiana ${ }^{1}$, and V. Totok Noerwasito ${ }^{1}$
}

\begin{abstract}
Lack of horizontal land causes the development of vertical buildings. Residences in major cities are dominated by apartments from the low rise to the high rise types. Based on the information cited from Vivanews May 2, 2010, the number of apartments in Surabaya approximately 12 new apartment projects and has been built with a total of 5,000 units with an average of nearly $80 \%$ is sold in every apartment. Current sheath material that is widely used for apartment's envelope is precast concrete. Precast concrete is the material that had been made at the factory in accordance with the form of the mold, then the molded concrete will be transported and installed to the building construction site. Precast concrete is chosen because it has several advantages when compared to conventional concrete structural system, including the efficiency of processing time, energy efficiency, and environmentally friendly. Given these statements, the researcher needs to know the thermal performance of apartment buildings (high-rise) in Surabaya with precast concrete building envelope. Expected to know the configuration of precast concrete materials in the building envelope, the researcher can construct an apartment building design proposals that meet the criteria of thermal comfort in tropical regions. This study aims to identify and explain the thermal performance of the precast concrete configuration in apartment buildings (high-rise) in Surabaya for the buiding envelope. The method that is used for this research is an experimental method to study the object with modeling strategies by Archipak for the simulation. The results shows that thermal performance of precast concrete pretty well applied to the apartment with thermal properties that support the value of the thermal performance of precast..
\end{abstract}

Keywords— Reciprocating Compressor, Valve Seat, Vibration, Pressure.

\section{INTRODUCTION}

$\mathrm{T}$ The impact of global warming is very significant on rising the temperature of environment. It affects the thermal performance of the building. Indonesia is one of the country with tropical climate and has a mayor issue of large solar radiation. One of the components of the building to play a role in this case is the building envelope. Building envelope is designed well to achieve a comfortable thermal conditions in the building and in accordance with the conditions of tropical climate. In the tropical climate conditions, the development of high-rise buildings affect the heating process. Heating of the building affected by the use of building elements. All building elements influence the achievement of thermal comfort in buildings. Hence the selection of building materials according to the specific climatic conditions is one of important factor in the building. (Santoso, 2007).

Prianto (2007) revealed that there are two categories based on the function of the thermal building, the building thermal load is dominated by the ability of the skin surface and the second is a thermal load that is formed due to internal activities. In the first case, if the building can not adapt and responds to the climate, the greater the total heat load occur in residential and consequently to obtain thermal comfort, occupant will use active cooling.

Budi (2001) revealed that the facade of the building serves as a shelter or refuge for a room in which the environment is affected by climatic conditions. But in its

${ }^{1}$ Romanria Violina Mahardhika, Ima Defiana, and V. Totok Noerwasito are with Departement of Environmental Architecture Faculty of Civil Engineering and Planning, Institut Teknologi Sepuluh Nopember, Surabaya, 60111, Indonesia. E-mail: violinamahardhika@gmail.com; imadefiana@yahoo.com; vitonoer@arch.its.ac.id. development, facade functions shifted into an aesthetic function. So that activity can take place in a comfortable building, is needed that a building design is able to anticipate the environmental influences that cause uncomfortable conditions. One of building element that is expected to anticipate the environmental factors is the building facade.

Current sheath material that widely used in apartments is precast concrete. Precast concrete is a material that had been made at the factory in accordance with the form of the mold, then the molded concrete will be transported and installed to the building construction site. Precast concrete is chosen because it has several advantages when compared to conventional concrete structural system, including the efficiency of processing time, energy efficiency, and environmentally friendly.

This study aimed at Surabaya with high-rise apartments the focus of this research is a form of apartment configurations using precast concrete to analyze the thermal performance of the building. 1 tower apartment is taken to avoid shadowing from other tower and make it easier to analyze the influence of the thermal performance of the material in the building facade. Apartment using active ventilation so it would be steady state. Simulation is not done per floor of the building, but calculate the volume of the building. Precast concrete that is used in this research is based on the thickness i.e. $75 \mathrm{~mm}, 100 \mathrm{~mm}$, and $125 \mathrm{~mm}$.

\section{A. Building Envelope in Tropical Region}

According Priatman (1999), the building envelope is part of the building that covered with a protective layer to protect the interior of the building around the climatic conditions. Associated with thermal performance, determining the composition of the facade is the use of building materials as a heat transfer from the outside of the building either by conduction, convection and radiation. The surface area of the walls and glass 
(window to wall ratio), imagery, U-value, the conductance material and glass walls, shading coefficient are essential elements in the facade.

There is a difference in the steady state condition of the wall and the temperature changing. At different temperature conditions remain the same use within the specified period, the resulting heat flow is relatively constant from higher temperature to lower. In contrast to the varied temperature conditions, the capacity of the material to store heat needs to be calculated. For example when there is a rise in the temperature of the outside air, the walls will absorb the heat. If the wall can not store the heat, then the heat will flow out into the room with lower temperature (Frick,2008). Based on this statements, proper material is needed to keep the quality of indoor temperature.

\section{B. Thermal Comfort}

According Szokolay (2004) thermal comfort is a state of mind which showed satisfaction with the thermal environment, and requires a subjective evaluation. Factors that affect thermal comfort is a factor of personal and physical factors. Personal factors include the activity (the higher the activity, the greater the heat loss); clothing (as a thermal insulator for the body and skin to maintain comfortable temperature), age (the average heat emission decreases with age), and gender. Physical factors of thermal comfort are air temperature and surface (heat radiation body heat radiation affected the environment and the air temperature); air movement (helps increase the release of body heat by convection) and humidity (40\%-70\%).

Range of thermal comfort conditions are generally referred to as the comfort zone. Temperature limits of the comfort zone can be calculated from the neutral temperature $\pm 2.5^{\circ} \mathrm{C}$. Neutral temperature is needed to know the neutral temperature on the hottest and coldest month in a year.

Calculation of the reference range as a comfort range calculation comfort in hot and cold need to know. This calculation is necessary because the range of comfort in both hot and cold experience the difference. At Szokolay (2004) there is a strategy based on the calculation of the equation Thermal comfort range Neutrality (Tn) as follows:

$\mathrm{Tn}=17.6+0.31 \mathrm{xTo} . \mathrm{av}$

where:

$\mathrm{Tn}=$ thermal neutrality

To.av = average temperature in a month.

After doing the calculations Tn, it can determine the range of the upper and lower ranges of temperature within 1 month of the following ways:

$\mathrm{Tn}+1.75$ (upper limit)

Tn - 1.75 (lower limit)

1.75 is a constant value for the calculation of temperature comfort range at 1 month. Comfortable temperature range in 1 month is the calculation of the formula above.

\section{METHOD}

\section{A. Research methods}

1) This research is using simulation and modelling to determine the thermal performance of precast concrete. The performance of precast concrete is performed by simulations using a computer program to determine the effect of modification with Archipak to analyze the facade elements to its performance as a thermal insulator.

2) This research is using mathematical formulas to support the data for this research.

\section{B. Sampling}

Sampling was done in a difficult study to examine the entire population of the research object. Sampling can select the object that taken from a unit or whole to get an idea of the unity. In this study are not the random sampled. The data is from 22 apartments in Surabaya, taken 1 dominant building typology is used as a form of apartments in Surabaya. From these data, there are 8 apartments in Surabaya with rectangular typology, for example Trillium, the Via and the Vue, Peak Marina, Metropolis, etc. From these 8 samples, there is 1 existing building as a module in this study and have been adjusted with a limitation of the study. Puri Matahari is taken as representative of the existing apartment buildings with a single tower type with rectangular typology. Here is the existing of Puri Matahari shown in Figure 1-3.

Thermal performance of the material will be calculated based on the volume of the building. It aims to determine the role of the building facade material with temperature in the apartment building.

\section{Mathematics}

In this research, mathematic formulas is used to find out the thermal properties of precast concrete with different thickness. Szokolay (2004) revelead the formulas to find out the thermal properties. Below is the formula to find the thermal properties of materials.

1) Diffusity

$$
\begin{aligned}
& \propto=\frac{\tau}{\rho \cdot \mathrm{c}} \\
& \propto=\text { thermal diffusity }\left(\mathrm{m}^{2} / \mathrm{s}\right) \\
& \tau=\text { thermal conductivity }(\mathrm{W} / \mathrm{mK}) \\
& \rho=\operatorname{density~}\left(\mathrm{kg} / \mathrm{m}^{3}\right) \\
& \mathrm{c}=\operatorname{specific~heat~capacity~}(\mathrm{J} / \mathrm{kg} \mathrm{K})
\end{aligned}
$$

2) Time lag

$$
\begin{aligned}
& \Phi=\frac{\mathrm{b}}{2} \sqrt{\frac{24}{\pi \cdot \propto}} ; \frac{1}{2} \sqrt{\frac{24}{\pi}}=1,38 \\
& \Phi=1,38 . \mathrm{b} \sqrt{\frac{1}{\epsilon}} \\
& \mathrm{b}=\text { thickness }(\mathrm{m}) \\
& \propto=\text { thermal diffusity }\left(\mathrm{m}^{2} / \mathrm{s}\right)
\end{aligned}
$$

3) Admittance

$$
\begin{aligned}
& \gamma=\frac{b^{2}}{\propto} \\
& b=\text { thickness }(\mathrm{m}) \\
& \propto=\text { thermal diffusity }\left(\mathrm{m}^{2} / \mathrm{s}\right)
\end{aligned}
$$

4) Decrement factor

$$
\begin{aligned}
& \mu=\exp \left(-b \sqrt{\frac{\pi}{\alpha .24}} ; \sqrt{\frac{\pi}{24}}=0,362\right. \\
& \mu=\exp \left(-0,362 \cdot b \sqrt{\frac{1}{\alpha}}\right) \\
& b=\text { thickness }(\mathrm{m}) \\
& \propto=\text { thermal diffusity }\left(\mathrm{m}^{2} / \mathrm{s}\right)
\end{aligned}
$$


$\exp =2,71828$

\section{RESULT AND DISCUSSION}

\section{A. Reciprocating Compressor Cycle}

The understanding of a reciprocating compressor can be started from a P-V diagram. In Figure 1, horizontal direction illustrates a fluid volume and a vertical direction illustrates a pressure, in one cycle of a reciprocating compressor. An actual P-V diagram of a reciprocating compressor is shown in Figure 1, where an ideal reciprocating compressor $\mathrm{P}-\mathrm{V}$ diagram is without losses. Areas above and below an A-B-D-E curve indicate power which are needed to activate valves and to overcome resistances in dealing with opening and closing both discharge and suction valve. The above diagram can be converted into P- $\theta$ diagram, where a horizontal axis indicates a crank angle and a vertical axis indicates a pressure, as shown in Figure 2.

A-B curve illustrates an expansion step of a reciprocating compressor, where air volume expands and its pressure drops. In B-C curve air has negative pressure (below the line of suction pressure), as a result of downward piston movement until the piston reaches bottom dead center. When the piston reaches BDC, the pressure meets the line of suction pressure, where the suction port is closed. In C-D curve the piston moves from BDC to top dead center. The compression stage happens, and air pressure increases. Actually point $\mathrm{D}$ is above the line of discharge pressure. The discharge port opens from point $\mathrm{D}$ until air pressure reaches the line of discharge pressure (point $\mathrm{E}$ or A). And the cycle repeats itself.

\section{B. Vibration}

Machinery which has moving parts will yield a mechanical motion when it operates. This mechanical motion will produce vibration in the machine. A particular vibration level will induce or indicate a failure in one or more than one parts of machinery. Vibration varies with location; therefore each location can have a different vibration profile. Commonly, for the purpose of analysis, vibration monitoring is conducted only in certain points.

The working principle of a transducer is to capture a vibration signal and convert it into an electrical signal, and then send a signal to a data logger. Based on the kept data, vibration visualization can be done to make further analysis. Amplitude is the main indicator for assessing the condition of machinery.

Vibration which happens on reciprocating compressor takes place because of an excitation force that appears. This excitation force is caused by variation of a cylinder chamber pressure and imbalance due to the crankshaft operation. Vibration is mainly caused by open-close processes of valves. The open-close motions of valves generate impacts on valve seats and valve heads. The ensuing impacts are put through the compressor body and materialized as vibration.

Significant amplitudes are commonly caused by four happenings: discharge valve open, discharge valve close, suction valve open, suction valve close.

\section{Valve Component}

The studied valve is a flat plate type, shown in Figure 3. The valve consists of four main components: valve seat, stop plate (guard), valve plate (sealing), spring.
Schematically, Figure 4 shows a discharge valve seat as supplied by the vendor (manufacturer). The discharge valve seat as supplied by the vendor is called the valve seat with normal (unmodified) profile.

\section{METHOD}

Acquired data for this study are from an air reciprocating compressor, with the following specification:
a. Type
b. Speed
c. Power
d. Drive
: single stage, single acting
: $630 \mathrm{rpm}$
: $2 \mathrm{HP}$
: electrical motor 380 volt, $1430 \mathrm{rpm}$
e. Working pressure : $7 \mathrm{~kg} / \mathrm{cm} 2$
f. Speed reduction : belt transmission

The two variables being measured are vibration acceleration of a cylinder head and a pressure of a cylinder chamber. Both variables are taken simultaneously, and then are plotted against a crank angle. Measurement at the same time is triggered by used of a tachometer. Measurement data are recorded by a data logger, which in turn are downloaded to a digital computer, so that cylinder chamber pressure and vibration graphs can be displayed. Varied working pressures are conducted to verify the effects of modified valve seat profiles.

On the outer side of a cylinder head is placed an accelerometer equipped with a magnetic base to measure the ensuing vibration. A hole is drilled in the cylinder head to place a pressure transducer, so that a chamber pressure can be measured. The vibration and the cylinder chamber pressure are measured at the same time, i.e. both signals are measured at the corresponding crank angle. Data are taken for different discharge valve seat designs, as shown by Figure 7. Each design is applied on the compressor, in order to know its effect on the compressor.

\section{RESULT AND ANALYSIS}

\section{A. Climatic data}

This study aimed to determine the effect of climate on the adaptive capacity building facade materials that affect the thermal performance of the apartment. Climatic conditions used were data from Juanda BMG 2012.

Surabaya is located in $7.09^{\circ} \mathrm{LS}-7.21^{\circ} \mathrm{LS}$ and 112.36oBT-112.54oBT and lies at an altitude of $3 \mathrm{~m}-6 \mathrm{~m}$ of sea level. Surabaya tends to be high-temperature conditions throughout the year. In this study, the components that affect climate are solar radiation and air temperature. Table 1 lists of maximum temperature, minimum temperature and the average temperature of Surabaya during the last 5 years.

\section{B. Research methods}

Existing chosen in this study is an apartment located at the HR.Muhammad street, Surabaya with rectangular building typologies with 1 Tower. Orientation to the South, the Sun Castle apartments consist of 30 floors with 357 residential units. Sun Castle apartment is an apartment with a residential unit leased to the systems 
and services such as hotel without a kitchen. Apartment Puri Matahari chosen as existing from the 11 other apartments by the provisions made as it is considered the most appropriate in terms of typology (rectangle), orientation (south / north), and the single tower that had been set in the study limitation. Thermal performance of the material will be calculated based on the volume of the building. It aims to determine the role of the building facade material with temperature in the apartment building.

Table 1 shows the existing material of Puri Matahari. For the models, the materials will be replaced with precast concrete with different thickness.

\section{The Moduls}

Existing chosen in this study is an apartment located at HR.Muhammad street, Surabaya with rectangular building typologies with 1 Tower. Orientation to the South, the Puri Matahari apartments consist of 30 floors with 357 residential units. Sun Castle apartment is an apartment with a residential unit leased to the systems and services such as hotel without a kitchen.Apartment Puri Matahari chosen as existing from the 11 other apartments by the provisions made as it is considered the most appropriate in terms of typology (rectangle), orientation (south / north), and the single tower that had been set in the study limitation.

There are 3 moduls for this research. The variables that influence the moduls is the thickness of precast and glazing ratio of the building.

Table 2 shows the thermal properties by apllying the Szokolay's formulas.

Here is a neutral temperature range calculation on February and October based on Szokolay (2004) formulas:

$$
\begin{aligned}
& \text { a. February } \\
& \mathrm{Tn}=17,6+0,31 \times \text { To.av } \\
& \mathrm{Tn}=17,6+(0,31 \times 27,5) \\
& \mathrm{Tn}=26,13 \\
& \text { Upper limit = Tav }+1,75 \\
& =26,13+1,75 \\
& =27,9 \\
& \text { Lower Limit = Tav }-1,75 \\
& =26,13-1,75 \\
& =24,4
\end{aligned}
$$

So comfortable temperature range is 24.4 to $27.9^{\circ} \mathrm{C}$ on February

b. October

$\mathrm{Tn}=17,6+0,31 \times$ To.av

$\mathrm{Tn}=17,6+(0,31 \times 29,5)$

$\mathrm{Tn}=26,8$

Upper limit $=$ Tav $+1,75$

$=26,8+1,75$

$=29$

Lower limit $=$ Tav $-1,75$

$=26,8-1,75$

$=25$

So comfortable temperature range is 25 to $29^{\circ} \mathrm{C}$ on October

\section{Calculating Internal Heat Gain}

Internal heat gain during 24 hours on the activities take place in apartments and buildings that contribute to heat gain one of the factors that increase the internal temperature. Internal heat gain derived from human activities and equipments. Apartments are residential units so that the internal heat gain is large enough. In this study the internal heat gain is assumed to be based on the amount of people and equipment that may be used.

\section{E. Determination of Air Change in air-conditioned buildings Conditions}

Decreasing in temperature can occur with the help of air change in the space or commonly called air change. At steady state conditions or when air is used as an aid lowering the temperature and control the air conditioning in the room temperature, then the air change in building is 2-5 (Szokolay, 2008). 2 ach value will be used to input in the coldest month (February) and 5 ach value will be used in the input data is the hottest month in the year 2012 ie October. Thermal performance of the material is calculated on a unit volume of apartment buildings. Ach value will be multiplied by the number of existing floor, with a steady state then needs ach of building.

\section{F. Thermal Analysis of Puri Matahari Apartments in Coldest Months (February) and Hottest Months (October) with Material Precast Concrete $75 \mathrm{~mm}$}

Below is a graph of air temperature in the building on February with a steady state condition shown in Figure 4.

There are uncomfortable zone in February when the air temperature is below the comfort zone. 00:00 to 07:30 o'clock in the building air temperature is less than $20^{\circ} \mathrm{C}$ and between 20.00-24.00 at air temperatures below 24.4 ${ }^{\circ} \mathrm{C}$ to temperatures down to $-20^{\circ} \mathrm{C}$, this occurs because the outside air temperature is also small. In February, there is a comfort zone in a span of 07:30 to 21:00 o'clock. During 13.5 hours, the temperature in the building is habitable by its owner. Load AC started at 08.00 until 18.00. Total load AC in February reached 19006.4 kWh with Sensible load of $13754 \mathrm{kWh} \mathrm{/} \mathrm{day}$ and latent load of $5252.4 \mathrm{kWh} /$ day. The highest load at 14.00 (peak hour) when the outside air temperature of $34.4^{\circ} \mathrm{C}$ is equal to $2660.3 \mathrm{kWh}$.

Below is a graph of air temperature in the building on October with steady state conditions shown in Figure 5 October is the hottest month in 2012. in October, the uncomfortable zone is in the starting at 10:00 to 21:00, in the span of 11 hours, the building requires artificial ventilation to reduce the temperature of the temperature in the building. AC can help lower the building temperature and the outside temperature is below but not yet in the comfort zone, which is $29.3^{\circ} \mathrm{C}$ starting at 07:00 to 18:00. 00:00 to 7:30 pm and in the range of 18.30-24.00 at air temperatures are in the comfort zone in October in the amount of 25-29oC. Load AC started at 08.00 until 18.00. Total AC load in October reached $30906 \mathrm{kWh}$ with Sensible load of $15675.8 \mathrm{kWh} /$ day and latent load of $15230.2 \mathrm{kWh} /$ day. Highest load at 14.00 (peak hour) when the outside air temperature of $36.7^{\circ} \mathrm{C}$ is equal to $4008.6 \mathrm{kWh}$.

G. Thermal Analysis of Puri Matahari Apartments in Coldest Months (February) and Hottest Months (October) with Material Precast Concrete $100 \mathrm{~mm}$

Below is a graph of air temperature in the building on February with a steady state condition shown in Figure 6. There are uncomfortable zone in February when the air temperature is below the comfort zone. 00:00 to 7:30 pm 
and between $22.00-24.00$ at the air temperature in the building below the lower limit of the comfort zone is $24.4^{\circ} \mathrm{C}$ in February, it happens because the outside air temperature is also small. In February, there is a comfort zone in a span of 07:30 to 21:00 o'clock. During 13.5 hours, the temperature in the building is habitable by its owner. AC Load started at 08.00 until 18.00. Total AC load in February reached $19063.4 \mathrm{kWh}$ with Sensible load of $13760 \mathrm{kWh} /$ day and latent load of $5303.3 \mathrm{kWh} /$ day. Load highest at 14.00 (peak hour) when the outside air temperature of $34.4^{\circ} \mathrm{C}$ is equal to $2665.1 \mathrm{kWh}$.

Below is a graph of air temperature in the building in October with steady state conditions shown in Figure 7. As the hottest month in the year 2012 and the average outside temperature of $29.5^{\circ} \mathrm{C}$, air temperature also increased significantly. 00:00 to 7:30 pm a comfortable zone 1 with comfortable temperatures in the range in October is $25-29^{\circ} \mathrm{C}$. $07: 30$ to $18: 00$ at temperatures above the upper limit of the comfort zone that is equal to $29.3^{\circ} \mathrm{C}$. In zone 3 , which is at $18.00-24.00$, the air temperature in the building back in the comfort zone in October.

AC Load started at 08.00 until 18.00. Total AC load in October reached $31102.8 \mathrm{kWh}$ with Sensible load of $15724.9 \mathrm{kWh} /$ day and latent load of $15377.9 \mathrm{kWh} /$ day. Load highest at 14.00 when the outside air temperature of $36.7^{\circ} \mathrm{C}$ is equal to $4031 \mathrm{kWh}$ and the average load at peak hours in February was $4031 \mathrm{kWh}$.

\section{H. Thermal Analysis of Puri Matahari Apartments in Coldest Months (February) and Hottest Months (October) with Material Precast Concrete $125 \mathrm{~mm}$}

Below is a graph of air temperature in the building on February with a steady state condition shown in Figure 8. There are uncomfortable zone in February when the air temperature is below the comfort zone. 00:00 to 7:30 pm the air temperature in the building below the lower limit of the comfort zone is $24.4^{\circ} \mathrm{C}$ in February, it happens because the outside air temperature is also small. In February, there is a comfort zone within a time span of at 07.30-24.00. During 16.5 hours, the temperature in the building is habitable by its owner.

AC load started at 08.00 until 18.00. Total AC load in February reached $19469.1 \mathrm{kWh}$ with Sensible load of $13826.6 \mathrm{kWh} /$ day and latent load of $5642.5 \mathrm{kWh} /$ day. Load highest at 14.00 (peak hour) when the outside air temperature of $34.4^{\circ} \mathrm{C}$ is equal to $2638.1 \mathrm{kWh}$.

Below is a graph of air temperature in the building in October with steady state conditions shown in Figure 9. As the hottest month in the year 2012 and the average outside temperature of $29.5^{\circ} \mathrm{C}$, air temperature also increased significantly. 00:00 to 7:30 pm a comfortable zone 1 with comfortable temperatures in the range in October is $25-29^{\circ} \mathrm{C}$. $07: 30$ to $18: 00$ at temperatures above the upper limit of the comfort zone that is equal to $29.3^{\circ} \mathrm{C}$. In zone 3 , which is at 20.00-24.00, the air temperature in the building back in the comfort zone in October.

AC load started at 08.00 until 18.00. Total load AC in October reached $33003.6 \mathrm{kWh}$ with Sensible load of $16509.9 \mathrm{kWh} /$ day and latent load of $16493.8 \mathrm{kWh} /$ day. Load highest at 14.00 when the outside air temperature of $36.7^{\circ} \mathrm{C}$ is equal to $3972.2 \mathrm{kWh}$.

Precast concrete applications as the sheath material apartments in Puri Matahari can reduce the average temperature for 24 hours in comparison to the brick building plaster used on existing buildings. Precast concrete with a thickness of $75 \mathrm{~mm}$ can lower the temperature by $1.4^{\circ} \mathrm{C}$ compared to brick and plaster in October by $1.5^{\circ} \mathrm{C}$ in February.

Thermal performance of the material is affected by the thermal properties of the material. U-value, decrement factor, admittance, and time lag are the components of the thermal properties of materials that have established the role of the thermal performance of the material.

In general, time lag of precast concrete has significant differences with brick plaster. Time lag of brick plaster was $6.5 \mathrm{~h}$ while the average capacity of existing precast concrete is at $3.7 \mathrm{~h}$. from the result it can make a conclusion that precast could provide thermal comfort in the building.

\section{REFERENCES}

[1]. Akmal, Imelda. (2007), Menata Apartemen, Gramedia

[2]. Agria (2012). "Perencanaan dan Perancangan Segreen Apartemen".

[3]. Evan,M. (1980). "Housing, Climate, and Comfort”. The Architectural Press Limited: London

[4]. Frick, Heinz; Ardiyanto, Antonius dan Darmawan, AMS. 2008 "Ilmu Fisika Bangunan. Yogyakarta: Kanisius.

[5]. Heerwagen, Dean. (2004), "Passive and Active Environmental Controls”, McGraw-Hill Publishing Company Ltd:New York

[6]. Givoni, Baruch. (1998). "Climate Considerations in Building and Urban Design”.Van Nostrand Reinhold: New York.

[7]. Giovani, Orry (2008). "Analisa dan Perencanaan Pelat Beton Pracetak Sistem Hollow Core Slab (HCS) untuk Pelat Satu Arah”.

[8]. Lechner, Norbert (2001). “Heating, Cooling, Lighting”. John Wiley \& Sons, Inc: New York

[9]. Liping,Wang, Wong Nyuk Hien (2007). “The impacts of ventilation strategies and facade on indoor thermal environment for naturally ventilated residential buildings in Singapore”.

[10]. Lippsmeier, Georg. 1980. Bangunan Tropis. Erlangga: Jakarta.

[11]. Karyono, Tri Harso (2001). "Wujud Kota Tropis di Indonesia: Suatu Pendekatan Iklim, Lingkungan dan Energi”

[12]. McMullan, R (2007). "Sixth Edition: Environmental Science in Building”. Palgrave Macmillan:London.

[13]. Nurjanah, Siti Aisyah (2011). "Perkembangan Sistem Struktur Beton Pracetak Sebagai Alternatif Pada Teknologi Konstruksi Indonesia Yang Mendukung Efisiensi Energi Serta Ramah Lingkungan”.

[14]. Olgyay, Victor, (1992), Design with Climate. Van Nostrand Reinhold, New York.

[15]. Prastowo, Budi (2001). "Efektivitas Bentuk Fasad Gedung Henricus Consant Terhadap Pengendalian Temperatur"

[16]. Priatman, Jimmy (1999). “Tradisi dan Inovasi Material Fasad Bangunan Tinggi”

[17]. Romel, Erwin (2013). "Precast Concrete Wall”

[18]. Saputra, Handoko (2004). "Pengaruh Orientasi Bangunan Terhadap Penurunan Panas pada Rumah Tinggal Perumahan Wonorejo di Surakarta”.

[19]. Schueller, Wolfgang. (1977). "High-Rise Building Structure”. A Wiley Interscience Publication: New York

[20]. Samodra, FX. Teddy Badai (2008). "Spesifikasi Kinerja Termal Sistim Konstruksi Kulit Rumah Tinggal Tropis dalam Variasi Altitude”

[21]. Sukawi (2010). "Kaitan Desain Selubung Bangunan Terhadap Pemakaian Energi dalam Bangunan”.

[22]. SNI 6390:2012

[23]. Szokolay,S.V. (1987). “Thermal Design of Building”. RAIA Education Division: Canberra

[24]. Szokolay, Steven V. (2004), Introduction to Architectural Science, The Basis of Sustainable Design, Oxford, Burlington, Britain.

[25]. Talalosa, Basaria (2005). "Menciptakan Kenyamanan Termal dalam bangunan".

[26]. Wahyu Sujatmiko, Wisnu Hendradjit, Dan Soegijanto.” Menuju Penyusunan dan Penerapan Standar Kenyamanan Termal Adaptif di Indonesia”

[27]. Utomo, Darmawan (2008). "Pengaruh Desain Fasad terhadap Beban Pendinginan pada Apartemen di Daerah Tropis” 
[28]. Wonorahardjo, Surjamanto. “Dampak Penggunaan Bahan Bangunan pada Lingkungan Termal Studi kasus : Kota Bandung”

[29]. Yeang, Ken. (1994). “Bioclimatic Skyscrapers”. Artemis London: England

[30]. http://www.seris.sg/

[31]. http://abe.tudelft.nl/
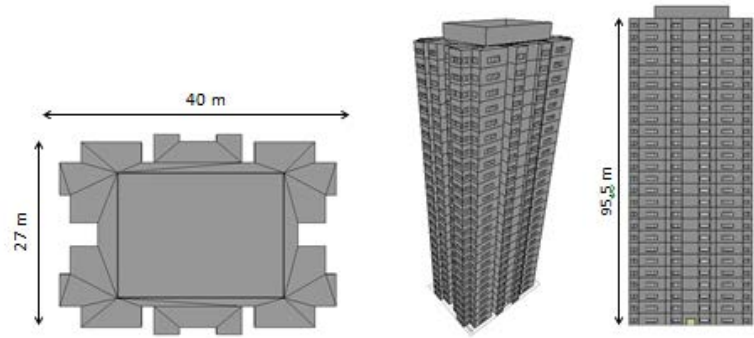

Figure 1. Plan and perspective of Puri Matahari
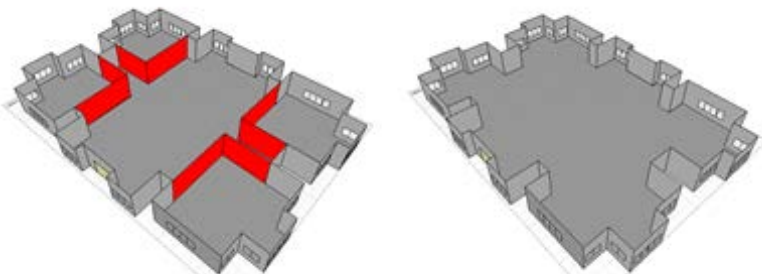

Figure 2. Layout dwelling units in an apartment wirh 5 zone (left), simplifying zoning space on the 1st floor. (right)

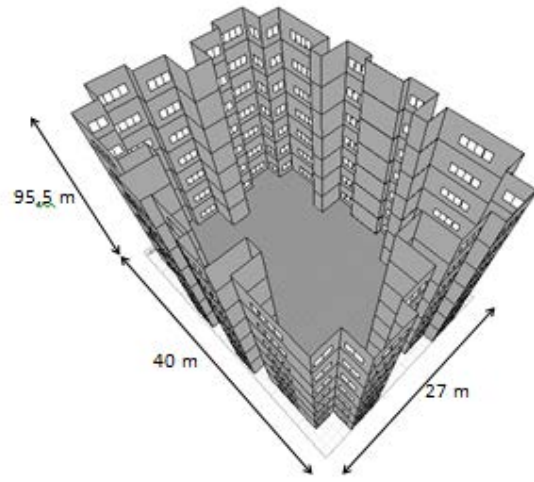

Figure 3. The model to evaluate in Archipak

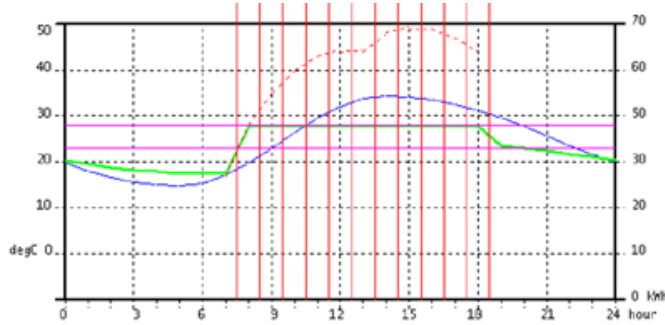

Temperature profiles and a/c load

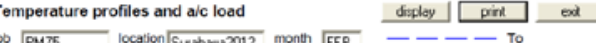

- -- To $_{\text {Ti }}$

Figure 4. Temperature chart in the building on February 2012 with precast concrete material $75 \mathrm{~mm}$
[32]. http://addyarchy07.blogspot.com/

[33]. http://digilib.petra.ac.id/

[34]. http://repository.upi.edu/

[35]. http://www.bsn.go.id/

[36]. http://greenarchizone.blogspot.com/

[37]. http://atjenese.wordpress.com/

[38]. http://herusu71.blogspot.com

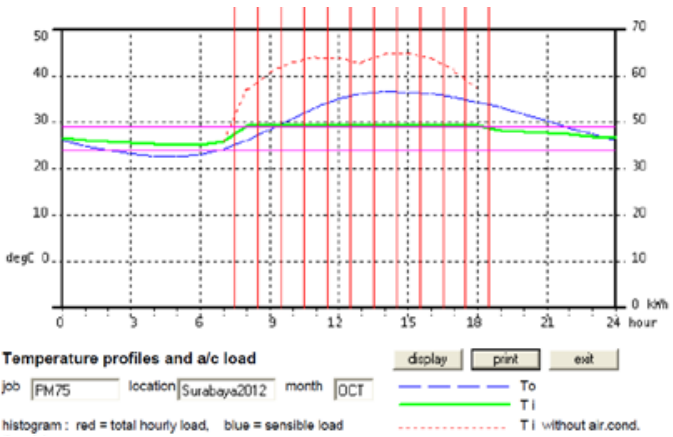

Figure 5. Temperature chart in the building on October

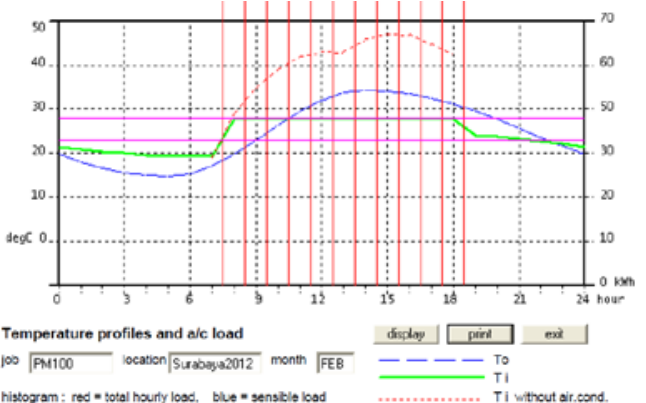

Figure 6. Temperature chart in the building on FebruRY

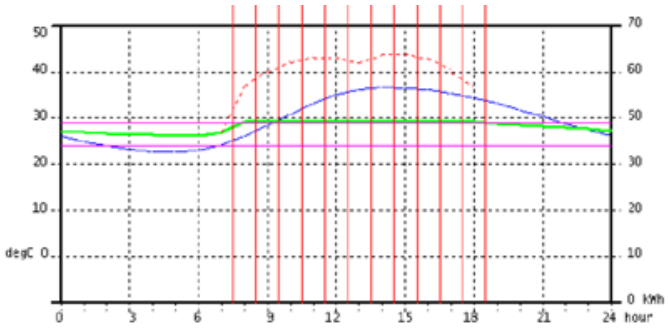

Temperature profiles and a/c load

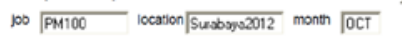

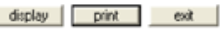

--- To $_{\text {Ti }}$

.

Figure 7. Temperature chart in the building on October 2012 with precast concrete material $100 \mathrm{~mm}$
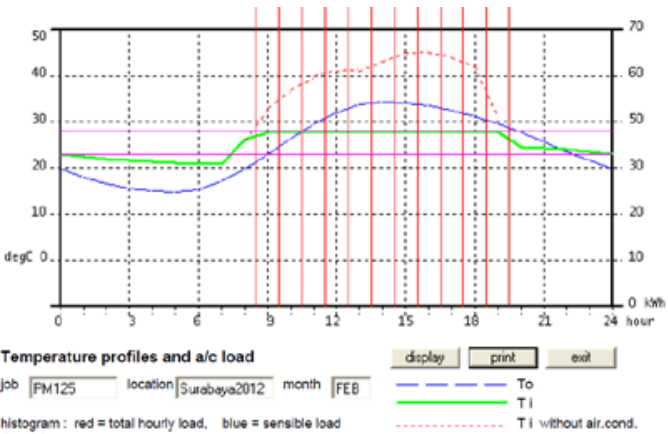

Figure 8. Temperature chart in the building on February 2012 with precast concrete material $125 \mathrm{~mm}$ 


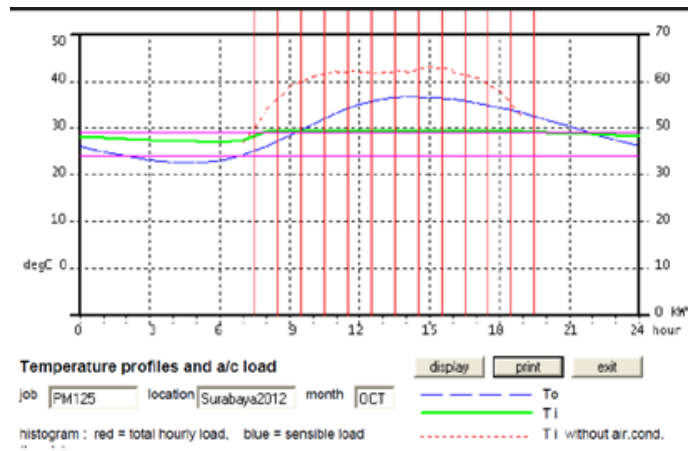

Figure 9. Temperature chart in the building on October 2012 with precast concrete material $125 \mathrm{~mm}$

TABLE 1.

SURABAYA CLIMATIC CONDITIONS IN 2012

\begin{tabular}{|l|c|c|c|c|c|c|c|}
\hline Month & $\begin{array}{c}\text { Irad } \\
{\mathrm{Wh} / \mathrm{m}^{2}}^{2}\end{array}$ & $\begin{array}{c}\text { T.max } \\
\left({ }^{\circ} \mathrm{C}\right)\end{array}$ & $\begin{array}{c}\text { T.min } \\
\left({ }^{\circ} \mathrm{C}\right)\end{array}$ & $\begin{array}{c}\text { T.av } \\
\left({ }^{\circ} \mathrm{C}\right)\end{array}$ & $\begin{array}{c}\text { RH.av } \\
(\%)\end{array}$ & $\begin{array}{c}\text { Wind } \\
\text { velocity }(\mathrm{m} / \mathrm{s})\end{array}$ & $\begin{array}{c}\text { Wind } \\
\text { dir }\end{array}$ \\
\hline Jan & 6912 & 34,8 & 22,1 & 27,1 & 83 & 4,3 & $270^{\circ}$ \\
\hline Feb & 7438 & 34,4 & 14,8 & 27,5 & 82 & 3,2 & $270^{\circ}$ \\
\hline Mar & 6485 & 34,1 & 22,6 & 27,4 & 81 & 4,6 & $270^{\circ}$ \\
\hline Apr & 5473 & 34,2 & 23 & 28,4 & 78 & 3,3 & $90^{\circ}$ \\
\hline May & 4538 & 33,4 & 20,1 & 27,8 & 78 & 3,4 & $90^{\circ}$ \\
\hline Juni & 4201 & 33,4 & 20,4 & 27,0 & 78 & 3,6 & $90^{\circ}$ \\
\hline July & 4563 & 33,4 & 20 & 26,3 & 84 & 3,6 & $90^{\circ}$ \\
\hline Aug & 5712 & 34,1 & 20 & 26,3 & 71 & 3,9 & $90^{\circ}$ \\
\hline Sep & 7172 & 34,6 & 21,7 & 26,6 & 69 & 4,0 & $90^{\circ}$ \\
\hline Oct & 7715 & 36,7 & 22,6 & 29,5 & 68 & 4,0 & $90^{\circ}$ \\
\hline Nop & 7594 & 35,2 & 22,5 & 27,9 & 72 & 3,6 & $90^{\circ}$ \\
\hline Dec & 6959 & 35,4 & 22 & 28,1 & 82 & 3,3 & $270^{\circ}$ \\
\hline Average & 6230.167 & 34,48 & 20,98 & 27,5 & 77,2 & 3,7 & \\
\hline
\end{tabular}

TABLE 2.

MATERIALS ELEMENT OF FACADE IN PURI MATAHARI

\begin{tabular}{l|l|l}
\hline FACADE ELEMENTS & $\begin{array}{c}\text { FACADE } \\
\text { MATERIALS }\end{array}$ \\
\hline Roof & $\begin{array}{c}\text { Concrete and } \\
\text { metal deck } \\
\text { insulated }\end{array}$ \\
\hline Wall & $\begin{array}{c}\text { Brick } \\
\text { plastered with } \\
\text { side }\end{array}$ \\
\hline Door & $\begin{array}{c}\text { both } \\
\text { Window }\end{array}$ & $\begin{array}{c}\text { Single glass with } \\
\text { tinted glass }\end{array}$ \\
\hline
\end{tabular}

TABLE 3.

THERMAL PROPERTIES OF PRECAST WITH DIFFERENT THICKNESS

\begin{tabular}{|l|l|l|l|l|}
\hline & $\begin{array}{c}\mathrm{U} \text {-value } \\
\mathrm{W} / \mathrm{m}^{2} \cdot \mathrm{K}\end{array}$ & $\begin{array}{c}\text { Time-lag } \\
\mathrm{h}\end{array}$ & $\begin{array}{c}\text { Admittance } \\
\mathrm{W} / \mathrm{m}^{2} \mathrm{~K}\end{array}$ & $\begin{array}{c}\text { Decrement } \\
\text { Factor }\end{array}$ \\
\hline Precast $75 \mathrm{~mm}$ & 3,45 & 2,7 & 3,86 & 0,49 \\
\hline Precast $100 \mathrm{~mm}$ & 3,23 & 3,35 & 5,92 & 0,41 \\
\hline Precast $125 \mathrm{~mm}$ & 3,03 & 4 & 8,4 & 0,35 \\
\hline
\end{tabular}

TABLE 4.

RESULT OF SIMULATION IN ARCHIPAK

\begin{tabular}{|l|c|c|c|c|}
\hline & $\begin{array}{c}\text { Total AC } \\
\text { Load Oct }\end{array}$ & $\begin{array}{c}\text { Total AC } \\
\text { Load Feb }\end{array}$ & $\begin{array}{c}\text { Comfort } \\
\text { zone Oct }\end{array}$ & $\begin{array}{c}\text { Comfort } \\
\text { Zone Feb }\end{array}$ \\
\hline Precast $75 \mathrm{~mm}$ & 30906,0 & 19006,4 & 13 hours & 13,5 hours \\
\hline Precast $100 \mathrm{~mm}$ & 31102,8 & 19063,4 & 13,5 hours & 13,5 hours \\
\hline Precast $125 \mathrm{~mm}$ & 33003,6 & 19469,1 & 11,5 hours & 16,5 hours \\
\hline
\end{tabular}

